\title{
AKUNTANSI KELEMBAGAAN EKONOMI SYARIAH DALAM PERSFEKTIF IWAN TRIYUWONO
}

\author{
Rahmaniar, Akhmad Dakhoir, dan Adelia Norain ${ }^{1}$ \\ Fakultas Ekonomi dan Bisnis Islam IAIN Palangka Raya
}

\begin{abstract}
Islam as a religion has been placed as an option and at the same teachings that provide guidance in human life adherents. Islamic economic development in Indonesia is progressing very rapidly, characterized by the emergence of sharia based financial institution. Financial institutions in practice cannot be separated from the financial statements or called in the language of business is accounting. This study focused on mentation of Iwan Triyuwono about the concept of sharia accounting, as stated in this theory that sharia enterprise theory and synergy binary opposition. The formulation of the problem in this study are (1) how the concept mentation of Iwan Triyuwono about sharia accounting? (2) how the relevance mentation of Iwan Triyuwono about accounting institutional of Islamic economics? Therefore the purpose of this study were (3) to describe the concept mentation of Iwan Triyuwono about sharia accountting (4) to describe the relevance mentation of about acoounting institutional of Islamic economics.

This type of research is the library research using hictorical research aproach, namely research conducted by collecting data or scientific papers aimed at the object of research or data collection is literature, or the study undertaken to solve a problem on basically rests on a critical and in depth study of the materials relevant book. The subjects used in this study is Iwan Triyuwono.

The results of this study indicate that the mentation of Iwan Triyuwono with shariah enterprise theory and the theory of binary opposition synergies already very relevan to formulate theories that previously exsited in modern accounting theory. But in practice has not been able to be applied fully in the Islamic economics institutions. Because of the needs of the industry if sharia accounting concept he put forward can be realized with either the creation of a network organization with the realities if divine power.
\end{abstract}

Keywords: islamic accounting, iwan triyuwono, institutional of islamic economics

\section{PENDAHULUAN}

\section{Latar Belakang}

Islam sebagai suatu agama telah ditempatkan sebagai suatu pilihan dan sekaligus ajaran dijadikannya pedoman dalam kehidupan umat manusia yang memeluknya. Keberadaan ajarannya telah memberikan arahan dalam pengembangan peradaban umat manusia, utamanya dalam bidang ilmu pengetahuan dan teknologi. Islam adalah agama bersifat terbuka, yang selalu memberikan keleluasaan kepada umatnya untuk berpikir ke depan, dalam rangka mencapai tingkat peradaban dan kemajuan yang lebih baik. ${ }^{2}$

Perkembangan ekonomi syariah kini sedang mengalami kemajuan yang sangat pesat di Indonesia. Tidak dapat dipungkiri lagi bahwa dengan berkembangnya ekonomi syariah sekarang

\footnotetext{
${ }^{1}$ Alumni Jurusan Ekonomi Islam, Program Studi Ekonomi Syariah Fakultas Ekonomi dan Bisnis Islam IAIN Palangka Raya, email: Norainadelia@gmail.com.

2 Muhammad, Akuntansi Syariah Teori dan Praktik Untuk Perbankan Syariah, Yogyakarta: UPP STIMYKPN, 2013, h. 3.
} 
ini mulai banyak bermunculan lembaga-lembaga keuangan yang menggunakan prinsip syariah. ${ }^{3}$ Lembaga keuangan syariah sebagai bagian dari sistem ekonomi syariah, dalam menjalankan bisnis dan usahanya juga tidak terlepas dari sistem syariah. Oleh sebab itu, lembaga keuangan syariah tidak akan mungkin membiayai usaha-usaha yang di dalamnya terkandung hal-hal yang diharamkan. Terkait dengan lembaga keuangan syariah, maka pentingnya untuk menata dari sistem pencatatan atau pengukuran.Sistem pencatatan atau pengukuran terkait dengan masalah pembukuan atau akuntansi. ${ }^{4}$

Akuntansi posisinya sangat penting dalam suatu lembaga keuangan atau perusahaan, dimana akuntansi sangat berperan dalam mengambil kebijakan untuk mengembangkan perusahaan. Tujuan akuntansi tersebut intinya adalah untuk memperoleh informasi keuangan sebagai pengambil suatu kebijakan oleh perusahaan ataupun pengguna laporan keuangan para stakeholders. Belakangan ini ada suatu peningkatan kepentingan terhadap bidang akuntansi menuju akuntansi dalam perspektif Islami atau akuntansi syariah. Salah satu aspek yang mendorongnya adalah dengan munculnya sistem perbankan syariah. Di pihak lain, aspek-aspek akuntansi konvensional tidak dapat diterapkan pada lembaga yang menggunakan prinsip-prinsip Islam. Oleh karena itu, perlunya standar akuntansi yang cocok bagi bank syariah.Tujuan dasar laporan keuangan akuntansi syariah yang dijelaskan oleh Iwan Triyuwono yang bersifat "materi" adalah untuk pemberian informasi (akuntansi), sedangkan yang bersifat "spirit" adalah untuk akuntabilitas. Kedua tujuan ini mutually inclusive, tujuan yang satu tidak dapat meniadakan yang lain, keduanya berada dalam kesatuan (unity) sebagaimana bersatunya badan dan ruh kita. Pemberian informasiseolah-olah merupakan "badan" sedangkanakuntabilitas adalah "ruh", "Badan" tidakakan eksis tanpa "ruh". Demikian juga sebaliknya"ruh" tidak dapat membumi tanpa“badan". 5

Iwan Triyuwono yang merupakan pengarang buku yang berjudul "Akuntansi Syariah (perspektif, metodologi dan teori)" mengemukakan akuntansi syariahmerupakan instrumen akuntabilitas yangdigunakan oleh manajemen kepada Tuhan (akuntabilitas vertikal), stakeholders, dan alam (akuntabilitas horizontal). Pemikiran ini mempunyai dua implikasi. Pertama, akuntansi syariah harus dibangun sedemikian rupa berdasarkan nilai-nilai etika (dalam hal ini adalah etika syariah) sehingga "bentuk" akuntansi syariah (dan konsekuensinya informasi akuntansi yang disajikan) menjadi lebih adil, tidak berat sebelah, sebagaimana kita temukan pada akuntansi modern yang memihak kepada para kapitalis (kreditor) dan memenangkan nilai-nilai maskulin, hal ini tertuang dalam pola konsep pemikiran beliau dalam shari'ah enterprise theory. Kedua, praktik bisnis dan akuntansi yang dilakukan manajemen juga harus berdasarkan pada nilai-nilai etika syariah dengan menggabungkan sifat maskulin dan feminim. Jika dua implikasi ini benarbenar ada, maka akuntabilitas yang dilakukan oleh manajemen adalah akuntabilitas yang suci. Pola konsep pemikiran beliau ini tertuang dalam konsep teori sinergi oposisi biner.

Berdasarkan latar belakang yang sudah diuraikan di atas mengenai akuntansi kelembagaan ekonomi syariahmenurut persfektif Iwan Triyuwono maka dapat dirumuskan permasalah-

\footnotetext{
3 Perkembangan Bank Syariah di Indonesia kini telah menjadi tolak ukur keberhasilan eksisitensi ekonomi syariah.Bank Muamalat sebagai bank syariah pertama dan menjadi pioner bagi bank syariah lainnya telah lebih dahulu menerapkan sistem ini ditengah menjamurnya bank-bank konvensional. Krisis moneter yang terjadi pada tahun 1998 telah menenggelamkan bank-bank konvensional dan banyak dilikuidasi karena kegagalan system bunganya, sementara perbankan yang menerapkan sistem syariah dapat tetap eksis dan mampu bertahan, lihat Nurul Ichsan Hasan, Perbankan Syariah (Sebuah Pengantar), Jakarta: GP Press Group, 2014, h. 104.

4 Kata akuntansi berasal dari bahasa Inggris, accounting, dalam bahasa Arabnya disebut "Muhasabah" yang berasal dari kata hasaba, hasiba, muhasabah, atau wazan yang lain adalah hasaba, hasban, hisabah, artinya menimbang, memperhitungkan mengkalkulasikan, mendata, atau menghisab, yakni menghitung dengan seksama atau teliti yang harus dicatat dalam pembukuan tertentu,http:/ / referensiakuntansi.blogspot.co.id/ 2012/ 07/ pengertian-akuntansi-syariah.html\#sthash.KLj88jFn.dpuf, diakses 17 maret 2016.

5 Iwan Triyuwono, Sinergi Oposisi Biner: Formulasi Tujuan Dasar Laporan Keuangan Akuntansi Syariah, Universitas Brawijaya: IQTISADJournal of Islamic EconomicsVol. 4, No. 1, Muharram 1424 H/ March 2003, pp. 79 - 90.
} 
an yang dapat dikaji dalam penelitian ini yaitu: bagaimana konsep pemikiran Iwan triyuwono tentang akuntansi syariah ? bagaimana relevansi pemikiran Iwan Triyuwono tentang akuntansi kelembagaan ekonomi syariah?

Penelitian ini merupakan jenis penelitian kepustakaan (library research), maka teknik pengumpulan data yang dilakukan dalam penelitian adalah pengumpulan data literer, yaitu dengan mengumpulkan bahan-bahan pustaka yang berkesinambungan (koheren) dengan objek pembahasan yang diteliti.

\section{DESKRIPSI TEORETIK}

\section{Akuntansi Syariah}

\section{Pengertian Akuntansi Syariah}

Akuntansi merupakan hal penting dalam bisnis sebab seluruh pengambilan keputusan bisnis didasarkan informasi yang diperoleh dari akuntansi. Pada setiap tahapan pengambilan keputusan keberadaan informasi mempunyai peranan penting, baik mulai dari proses pengidentifikasian persoalan, maupun memonitor pelaksanaan keputusan yang diterapkan. ${ }^{6}$

Secara etimologi, kata akuntansi berasal dari bahasa inggris, accounting, dalam bahasa Arabnya disebut "muhasabah" yang berasal dari kata hasaba, hasibah, muhasabah, atau wazan yang lain adalah hasaba, hasban, hisabah, artinya menimbang, memperhitungkan, mengkalkulasi, mendata, atau menghisab. Yakni menghitung dengan seksama atau teliti yang harus dicatat dalam pembukuan tertentu.Kata "hisab" banyak ditemukan dalam Al-Qur'an dengan pengertian yang hampir sama, yaitu berujung pada jumlah atau angka. Kata hisab dalam ayat-ayat tersebut menunjukkan pada bilangan atau perhitungan yang ketat, teliti, akurat, dan bertanggung jawab. Oleh karena itu, akuntansi adalah mengetahui sesuatu dalam keadaan cukup, tidak kurang, dan tidak pula lebih. Sebagaimana telah dibahas, akuntansi merupakan sistem yang mengolah transaksi menjadi informasi keuangan. Selanjutnya transaksi syariah adalah transaksi yang dilakukan berlandaskan hukum Islam. Dengan demikian, akuntansi syariah mengolah secara syariah terhadap transaksi-transaksi yang dijalankan sesuai syariah, yaitu berdasarkan hukum Islam yaitu Al-Qur'an dan Al-Sunnah.7

\section{Dasar Hukum Akuntansi Syariah}

Akuntansi merupakan praktik transformatif yang memiliki potensi kuat untuk mengubah segala sesuatu di dunia, menciptakan perbedaan atas kehadiran atau ketiadaannya, dan mempengaruhi pengalaman hidup individu-individu lain.Islam sangat memperhatikan aspek-aspek muamalah seperti perhatiaannya terhadap ibadah, dan mengkombinasikan antara keduanya dalam kerangka yang seimbang.

Dasar munculnya akuntansi syariah adalah al-Qur'an. Al Qur'an adalah sumber pokok bagi pandangan Islam. Ia merupakan kalam ilahi yang bersifat abadi yang diwahyukan kepada Nabi Muhammad al-Musahamah SAW. Pandangan Islam dengan segala aspeknya bertumpu dan berpegangan pada petunjuk al-Qur'an, baik dalam hal yang berkaitan dengan akidah akhlak atau syariah. Perintah melakukan pencatatan perhitungan (akuntansi) secara tegas dinyatakan dalam surat al-Baqarah ayat 282:

6IKIT, Akuntansi Penghimpun Dana Bank Syariah, Yogyakarta: Deepublish, 2015, h. 27

${ }^{7}$ Sony Warsono, Akuntansi Transaksi Syariah, Yogyakarta: Asgard Chapter, 2011, h. 26-27. 


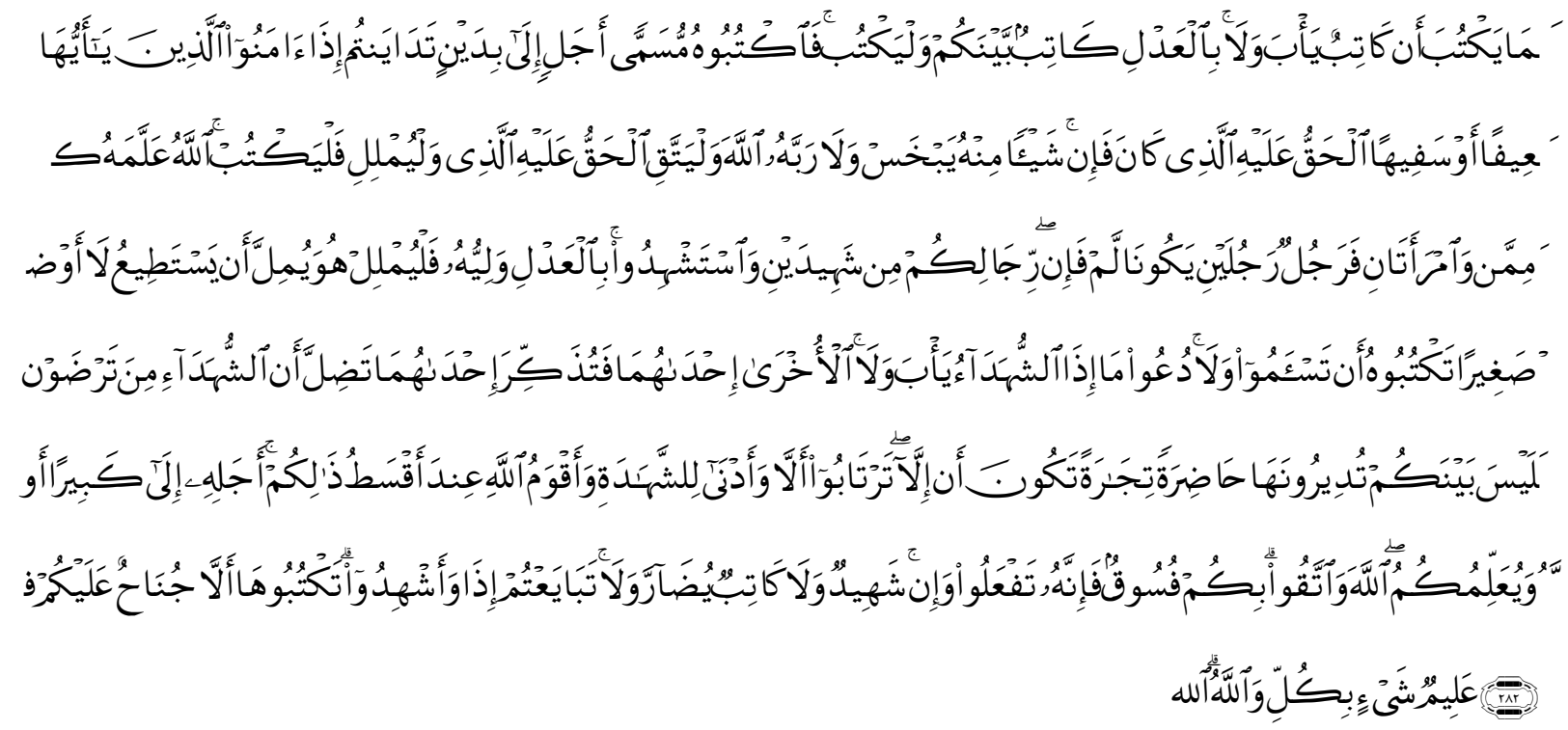

Artinya: "Hai orang-orang yang beriman, apabila kamu bermu'amalah tidak secara tunai untuk waktu yang ditentukan, Hendaklah kamu menuliskannya. Dan hendaklah seorang peneliti di antara kamu menuliskannya dengan benar. Dan janganlah peneliti enggan menuliskannya sebagaimana Allah mengajarkannya, Maka hendaklah ia menulis, dan hendaklah orang yang berhutang itu mengimlakkan (apa yang akan ditulis itu), dan hendaklah ia bertakwa kepada Allah Tuhannya, dan janganlah ia mengurangi sedikitpun daripada hutangnya. Jika yang berhutang itu orang yang lemah akalnya atau lemah (keadaannya) atau Dia sendiri tidak mampu mengimlakkan, Maka hendaklah walinya mengimlakkan dengan jujur. dan persaksikanlah dengan dua orang saksi dari orang-orang lelaki (di antaramu). jika tak ada dua orang lelaki, Maka (boleh) seorang lelaki dan dua orang perempuan dari saksi-saksi yang kamu ridhai, supaya jika seorang lupa Maka yang seorang mengingatkannya. Janganlah saksi-saksi itu enggan (memberi keterangan) apabila mereka dipanggil; dan janganlah kamu jemu menulis hutang itu, baik kecil maupun besar sampai batas waktu membayarnya. yang demikian itu, lebih adil di sisi Allah dan lebih menguatkan persaksian dan lebih dekat kepada tidak (menimbulkan) keraguanmu. (Tulislah mu'amalahmu itu), kecuali jika mu'amalah itu perdagangan tunai yang kamu jalankan di antara kamu, Maka tidak ada dosa bagi kamu, (jika) kamu tidak menulisnya. dan persaksikanlah apabila kamu berjual beli; dan janganlah penelitidan saksi saling sulit menyulitkan. jika kamu lakukan (yang demikian). Maka sesungguhnya hal itu adalah suatu kefasikan pada dirimu. dan bertakwalah kepada Allah; Allah mengajarmu; dan Allah Maha mengetahui segala sesuatu." 8

\section{Prinsip Akuntansi Syariah}

Adapun prinsip akuntansi syariah menurut Harahap di antaranya adalah mengakui hakhak Allah artinya semua yang ada di alam semesta ini baik berupa langit, bumi beserta sumber sumber alam, bahkan semua kekayaan yang dimiliki oleh manusia itu semuaya milik Allah karena Dialah yang menciptakan semuanya. Tugas manusia hanya mengelola, mengurus dan memanfaatkan alam semesta ini beserta isinya untuk kelangsungan dan kesejahteraan makhluk

${ }^{8}$ Depag RI, Al-'Aliyy Al-Quran dan Terjemahannya, Bandung: Diponegoro, t.th, h. 37. 
hidup, menjaga prinsip keadilan artinya pelaksanaan akuntansi syariah harus menjamin tegaknya keadilan dan kebenaran dalam segala sisi di operasional organisasi atau perusahaan. ${ }^{9}$

\section{Lembaga Keuangan Syariah \\ Pengertian Lembaga Keuangan Syariah}

lembaga keuangan adalah setiap perusahaan yang kegiatan usahanya berkaitan dengan bidang keuangan. Kegiatan usaha lembaga keuangan dapat berupa menghimpun dana dan menyalurkan dana sekaligus, di mana kegiatan usaha lembaga keuangan diperuntukkan bagi investasi perusahaan, kegiatan konsumsi, dan kegiatan distribusi barang dan jasa.

\section{Pembagian Lembaga Keuangan Syariah}

Lembaga keuangan dibagi kepada dua, yaitu lembaga keuangan bank dan lembaga keuangan nonbank.

\section{Fungsi Dan Peran Lembaga Keuangan Syariah}

Fungsi dan peran Lembaga Keuangan syariah di antaranya memenuhi kebutuhan masyarakat akan dana sebagai sarana untuk melakukan kegiatan ekonomi yang sesuai dengan prinsip-prinsip syariah.

\section{Teori Maqâsid Al-Syariah}

Salah satu konsep penting dalam kajian Islam adalah maqâsid asy-syarî'ah, yakni tujuan akan ditetapkannya hukum dalam Islam. Asy-Syatibi dalam kitabnya Al-muwafaqāt fi Ușūl alAkām sebagaimana yang dikutip oleh Asafri Jaya Bakri secara tegas menyatakan bahwa tujuan utama Allah menetapkan hukum-hukumnya adalah untuk terwujudnya kemaslahatan hidup manusia, baik di dunia maupun di akhirat. 10

Teori maqāsid syarī'ah sesuai untuk digunakan peneliti dalam menganalisis pemikiran Iwan Triyuwono tentang akuntansi kelembagaan ekonomi syariah. Dengan demikian, akan tercermin apakah akutansi syariah dalam kelembagaan ekonomi syariah sesuai dengan hukum Islam dan teori maqāsid syarīah yang mewujudkan nilai keadilan serta kemanfataan dalam hukum Islam atau sebaliknya. Peneliti memandang bahwa maqâsid asy-syarî'ah merupakan tujuan dari adanya aturan-aturan yang telah ditetapkan oleh Allh SWT. Semua aspek dalam kehidupan yang ada di muka bumi ini harus mengarah pada tercapainya kemaslahatan. Akuntansi syariah menempatkan maqâsid asy-syarî’ah sebagai acuan, karena maqâsid asy-syarî’ah tujuan dari pada syariah. Penempatan maslahah sebagai prinsip utama. Oleh karena itu aturan-aturan dalam syariah sangat terkait dengan berbagai dimensi aspek perilaku manusia. Aktivitas ekonomi tersebut harus menuju kepada kemaslahatan sehingga dapat memelihara maqâsid asy-syarî’ah.

\section{Konsep Pemikiran Iwan Triyuw ono Tentang Akuntansi Syariah Existing Implementasi Akuntansi di Lembaga Keuangan}

Existing implementasi akuntansi di lembaga keuangan juga memiliki peran yang sangat penting karena sebagaimana tujuannya akuntansi memberikan informasi keuangan yang akurat dan bermanfaat melalui jasa yang diberikan akuntansi. Kemajuan suatu kelembagaan dapat dilihat dari proses akuntansi perusahaan tersebut. Jika akuntansinya tersusun dengan baik dan benar maka dapat dipastikan aktivitas suatu lembaga keuangan dapat bejalan secara efektif dan efisien, karena adanya pengendalian sehingga tujuan dari suatu lembaga keuangan dapat ter-

9IKIT, Akuntansi Penghimpun Dana Bank Syariah, Yogyakarta: Deepublish, 2015, h. 38-39.

${ }^{10}$ Asafri Jaya Bakri, Konsep Maqashid Syariah Menurut Asy-Syatibi, Jakarta: RajaGrafindo Persada, Cet 1, 1996, h. 65. 
capai. Tetapi jika akuntansi di dalam kelembagaan tidak berjalan dengan baik maka kegiatan bisnisnya akan terhambat, tidak berjalan secara efektif dan efisien karena informasi yang dihasilkan tidak akurat, tentunya tujuan dari lembaga keuangan akan sulit dicapai. Oleh karena itu, suatu lembaga keuangan memerlukan akuntansi demi lancarnya kegiatan bisnisnya.

\section{Shari'ah Enterprise Theory}

Terkait dengan awal pemikiran Iwan Triyuwono, terlebih dahulu melihat bagaimana teori teori akuntansi kapitalis dalam pandangan Islam yaitu sebagai berikut.

1. Proprietary theory(Teori Kepemilikan)

Menurut Isgiyarta Proprietary theory adalah usaha atau perusahaan merupakan perpanjangan tangan dari pemilik. Isgiyarta menjelaskan bahwa dalam proprietary theory, perusahaan merupakan milik pemegang saham sehingga posisi utang akan mengurangi kekayaan perusahaan dan bunga diperlakukan sebagai beban usaha. ${ }^{11}$

Dapat dipahami bahwa konsep proprietary theory merupakan konsep kepemilikan dimana kepemilikan lebih diutamakan, dalam konsep ini juga pembagian keuntungan berdasarkan kepemilikan aset yang dimiliki dalam sebuah perusahaan.

2. EntityTheory (Teori Kekayaan)

Teori ini menganggap bahwa perusahaan memiliki eksistensi yang terpisah. Pemisahan ini terjadi pada kepentingan pemilik dan pemegang ekuitas yang lain.

Islam memandang kedua teori tersebut masih belum sempurna untuk dijadikan wadah untuk para stakeholders, karena masih dipengaruhi hak kepemilikan dan kekayaan. Artinya, teori-teori di atas dianggap tidak mampu untuk diterapkan di lembaga keuangan yang berbasis syariah. Maka dari itu, perlunya penyempurnaan teori-teori akuntansi yang sesuai dengan pandangan Islam. Lebih lanjut pembahasan mengenai enterprise theory yang menyatakan suatu perusahaan dipengaruhi oleh pihak langsung maupun tidak langsung yang memiliki peran penting dalam keberlangsungan perusahaan. Teori ini memiliki arti yang lebih luas dibandingkan teori sebelumnya karena dilihat dari segi akuntansi tanggung jawab pelaporan keuangan dalam perusahaan akan disampaikan kepada pemegang saham, kreditor juga kepada kelompok masyarakat secara keseluruhan (stakeholder).

Harahap berpendapat bahwa enterprise theory lebih lengkap dibandingkan dengan teori yang lain, karena ia melingkupi aspek sosial dan pertanggunjawaban. Berdasarkan ungkapan tersebut akuntansi syariah menurut Iwan Triyuwono merupakan salah satu upaya mendekontruksikan akuntansi modern ke dalam bentuk yang humanis dan sarat nilai. Tujuan diciptakannya akuntansi syariah adalah terciptanya peradaban bisnis dengan wawasan humanis, emansipatoris, transendental dan teleologikal.12

Terkait dengan Maqasid syariah dan perkembangan bisnis saat inimenurut Iwan Triyuwono proprietary theory dan entity theory tidak akan mampu mewadahi kemajemukan masyarakat (stakeholders) dan bisnis yang ada saat ini. Sebagaimana kita ketahui bahwasannya segala aspek muamalah tidak lepas dari maqasid syari'ah. Asafri Jaya Bakri mengungkapkan secara tegas menyatakan bahwa tujuan utama Allah menetapkan hukum-hukumnya adalah untuk terwujudnya kemaslahatan hidup manusia, baik di dunia maupun di akhirat.13

Untuk mengatasi hal ini diperlukan wadah alternatif yang lebih tepat dan sesuai dengan lingkungannya. Wadah tersebut menurut Iwan Triyuwono adalah Shari'ah enterprise theory, teori ini dianggap lebih menyeluruh/holistik, yakni dapat menyangkut aspek

\footnotetext{
${ }^{11}$ Isgiyarta,Teori Akuntansi dan Laporan Keuangan Islami, Semarang: Badan Penerbit Universitas Diponegoro, 2009, h. 89.

12Muhammad, Akuntansi Syariah., h. 151.

${ }^{13}$ Asafri Jaya Bakri, Konsep Maqashid Syariah Menurut Asy-Syatibi..., h. 65.
} 
kepemilikan pribadi atau kelompok dan juga pengakuan terhadap pihak lain sebagai faktor yang menentukan keberlangsungan sebuah perusahaan. Sebab konsep ini mencakup beberapa aspek yaitu moral, sosial, ekonomi, dan politik.Yang pada tujuannya membantu mencapai keadilan sosio-ekonomi, dan memberikan kesadaran sepenuhnya kewajiban kepada Tuhan, masyarakat, individu sehubungan dengan pihak-pihak yang terkait dengan aktivitas ekonomi.Konsep Shari'ah enterprise theory oleh Iwan Triyuwono dikembangkan berdasarkan pada metafora zakat pada dasarnya memiliki karakter keseimbangan. Secara umum, nilai keseimbangan yang dimaksud adalah keseimbangan antara nilai-nilai maskulin dan nilai-nilai feminim.

Menurut Iwan Triyuwono PSAK 59 masih sarat dengan nilai-nilai kapitalisme, terlihat dari perbankan syariah masih berorientasi pada pemilik modal. Meskipun PSAK 59 sudah berkembang menjadi PSAK 101-110. Kritikan Iwan Triyuwono dalam format laporan keuangan khususnya laporan laba rugi masih menganut sistem kapitalisme. Oleh karena itu, konsep income tidak lagi berorientasi padalaba (profit oriented) atau berorientasi pada pemegang saham (stockholders oriented), tetapi berorientasi pada zakat (zakat oriented).Pada akhirnya, konsep dan teori akuntansi yang berdasarkan Islam perlu dikembangkan oleh Iwan Triyuwono dengan penerapan konsep Shari'ah enterprise theory. Pemikirannya yang meorientasikan zakat sebagai tujuan dari akuntansi syariah jika dapat diterima dan dipraktikkan di lembaga keuangan syariah akan terciptanya realitas organisasi dengan jaringan kuasa ilahi. Namun konsep ini pula menurut Iwan Triyuwono tidak menutup kemungkinan untuk menerima kemajuan demi tercapai konsep akuntansi yang lebih syariah, sebaliknya konsep ini pula semua harus disertai dengan pembentukan masyarakat Islam yang sepenuhnya menjalankan syariat Islam dan pembentukan budaya serta perilaku umat menggunakan pendekatan normatif yang bersumber pada Al-Qur'an dan As-Sunah. Budaya, perilaku dan pola pikir yang Islami inilah yang akan membentuk sistem perekonomian yang dijalankan sesuai syariat Islam yang pada akhirnya akan membentuk konsep, teori dan praktik-praktik akuntansi yang Islami pula. Dengan konsep ini berarti aktiva bersih adalah milik pemilik sehingga memudahkan untuk meminta pertanggungjawaban kepada pemilik atas aktiva yang dimilikinya, baik itu dari segi pemanfaatan aktiva untuk kemaslahatan umat maupun dalam pengenaan zakat mal.

3. Sinergi Oposisi Biner

Teori Sinergi Oposisi Biner merupakan konsep keseimbangan yang memuat dalam akuntansi syariah, dengan menggabungkan antara prinsip akuntansi yang maskulin dengan prinsip yang feminim. Secara normatif tujuan laporan keuangan akuntansi syariah dapat diformulasikan sebagai perpaduan antara aspek-aspek yang bersifat materialistik dan spirituallistik; perpaduan "materi" dan "spirit". Akuntansi memang telah melakukan reduksi dengan mengkonsep laba dan rugi pada aspek keuangan saja, atau aspek materi saja. Konsep ini memperkuat persepsi manusia bahwa kebahagiaan itu adalah perolehan materi. Semakin banyak materi yang diperoleh seseorang, maka semakin bahagia orang tersebut. Tetapi dalam kenyataannya tidak demikian, materi bukan satu-satunya aspek dari kebahagiaan. Oleh karena itu, akuntansi mempunyai peluang untuk melakukan perubahan dengan menggunakan peran transformatifnya, yaitu dengan memasukkan "yang lain" pada yang ada di "sentral." Dengan kata lain, perlu mengawinkan "materi" (ekonomi, uang, struktur, dan lain-lainnya) dengan "spirit" (etika, kasih sayang, dan lain-lainnya). Dengan demikian, tujuan dasar dari laporan keuangan akuntansi syariah adalah perpaduan antara "materi" dan "spirit."14

14Ibid., h. 340-341. 
Bahwa tujuan dasar laporan keuangan akuntansi syariah yang bersifat "materi" adalah untuk pemberian informasi (akuntansi), sedangkan yang bersifat "spirit" adalah untuk akuntabilitas. ${ }^{15}$ Di antara berbagai laporan keuangan tersebut, laporan posisi keuangan dan laporan laba rugi merupakan dua laporan keuangan utama. Laporan keuangan lain seperti laporan arus kas, laporan perubahan ekuitas, laporan sumber dan penggunaan dana zakat. Biasanya laporan keuangan yang disajikan lembaga keuangan hanya yang bersifat komersil sedangkan yang non komersil tidak disajikan dalam laporan keuangannya. Ditinjau dari sinergi oposisi biner, maka laporan keuangan yang komersil hanya memenuhi dari segi materi. Dari segi spirit yang menyajikan laporan keuangan non komersil belum terpenuhi. Jika dilihat dari standar akuntansi, terdapat ketidakseimbangan, di satu sisi laporan keuangannya hanya untuk kepentingan pemilik dana, di sisi lain keharusan penyusunan laporan keuangan untuk pengguna selain pemilik dana. Inilah yang menjadi perhatian Iwan Triyuwono dalam teorinya sinergi oposisi biner. Menurutnya, laporan keuangan harus seimbang antara yang komersil dan yang non komersil. Langkah yang dapat dilakukan adalah dengan cara mengawinkan sifatsifat yang bertentangan (oposisi biner) ke dalam satu kesatuan. Misalnya, mengawinkan sifat egoistik dengan altruistik, sifat materialistik dengan spiritualistik, rasional dengan intuisi, impersonal dengan personal, kuantitatif dengan kualitatif, standarisasi dengan proliferasi, dan lain-lainnya.Inilah yang dimaksud dengan sinergi oposisi biner. Dengan sinergi ini diharapkan bahwa akuntansi akan memiliki power yang lebih kuat melalui pancaran informasi akuntansi yang dihasilkannya untuk kemudian membentuk realitas yang lebih humanis, emansipatoris, transendental, dan teleologikal. ${ }^{16}$

Jadi, lembaga keuangan dalam bentuk laporannya antara materi dan spirit harus saling seimbang. Laporan keuangan komersil merupakan bentuk dari aspek materi sedangkan laporan keuangan non komersil merupakan bentuk aspek dari spirit. Jika keduanya saling bersinergi antara yang materi dan spirit maka realitas bisnis dalam realitas ketauhidan akan terwujud. Dengan sinergi ini diharapkan bahwa akuntansi akan memiliki power yang lebih kuat melalui pancaran informasi akuntansi yang dihasilkannya untuk kemudian membentuk realitas yang lebih humanis, emansipatoris, transendental, dan teleologikal.

\section{Relavansi Pemikiran Iwan Triyuwono tentang Akuntansi Kelembagaan Ekonomi Syariah}

Pengembangan akuntansi syariah sebagai bagian dari bidang ilmu akuntansi masih tergolong baru dan masih memerlukan proses ilmiah yang cukup panjang untuk menjadi teori yang sempurna.Berdasarkanbahan kajian konsep shari'ah enterprise theory dan sinergi oposisi biner. Pokok akuntansi yang ditawarkan oleh Iwan Triyuwono ini merupakan konsep holistik yang mencakup segala aspek, dengan konsep metafora amanah dan zakat. Gambaran relevansi pemikiran Iwan Triyuwono tentang akuntansi kelembagaan ekonomi syariah. Dengan mengulas sedikit perkembangan paradigma akuntansi syariah, sebagaimana pernyataan Iwan Triyuwono, bahwa aliran pemikiran akuntansi syariah terbagi menjadi dua. Memang benar jika konsep akuntansi syariah di kelembagaan ekonomi syariah sudah banyak diterapkan, hanya saja dalam perkembangannya pemikiran ini berkembang dalam 2 golongan paradigm, yaitu akuntansi syariah filosofis teoretis dan akuntansi syariah praktis. Iwan Triyuwono menyatakan dirinya bagian dari pemikiran pada aliran pemikiran akuntansi syariah filosofis-teoritis. Yakni aliran pemikiran yang mencoba dan berusaha untuk melahirkan teori-teori akuntansi yang lahir dari ajaran Islam tanpa adanya campuran pemahaman dari akuntansi konvensional.

\footnotetext{
15Iwan Triyuwono, Akuntansi Syariah..., h. 332.
}

16Ibid., h. 338-340. 
Terkait dengan relevansi pemikiran Iwan Triyuwono konsep akuntansi syariah di kelembagaan ekonomi syariah, ini maka dapat peneliti pahami bahwa Iwan Triyuwono mencoba merumuskan tujuan akuntansi syariah dengan bervariasi melalui konsep teologi pembebasan tauhid menetapkan bahwa tujuan akuntansi syariah adalah sebagai instrumen untuk membebaskan manusia dari ikatan jaringan kuasa kapilatisme atau jaringan kuasa lainnya yang semu, dan kemudian diikatkan pada jaringan kuasa ilahi. Hal ini senada dengan apa yang dikemukakan oleh Harahap yang mencoba untuk menjelaskan tujuan akuntansi syariah dengan mengungkapkan bahwa kebenaran, kepastian, keterbukaan, keadilan, dan akuntabilitas dari transaksi yang dilakukan oleh perusahaan. Adapun secara teori, kajian Triyuwono ini mencoba mengkonsep laba dalam konteks metafora zakat. ${ }^{17}$

Adapun akuntansi syariah praktis adalah praktik akuntansi pada lembaga keuangan syariah. Kehadiran lembaga keuangan syariah menuntut hadirnya metode pencatatan untuk transaksi-transaksi syariah pada lembaga keuangan syariah. Akuntansi syariah yang secara teori belum mapan untuk diterapkan mengharuskan lembaga keuangan syariah menerapkan akuntansi konvensional dengan penyesuaian-penyesuaian dengan prinsip syariah. Pendekatan yang digunakan oleh akuntansi syariah praktis adalah pendekatan pragmatis. Pendekatan pragmatis terdiri dari penyusunan teori yang ditandai dengan penyesuaian praktik sesungguhnya yang bermanfaat untuk memberi saran solusi praktis.jika kita perbandingkan relevansi pemikiran Iwan Triyuwono masih belum mampu diterapkan seutuhnya di kelembagaan ekonomi syariah sebab perkembangan akuntansi syariah praktis akan selalu lebih maju dari akuntansi syariah filosofis-teoritis, karena merupakan kebutuhan industri. Kajian-kajian akuntansi syariah praktis lebih banyak dan lebih diminati. Hal ini menandakan perbankan syariah belum $100 \%$ syariah. Masih diperlukan penyempurnaan teori-teori dan praktik yang menjadikan akuntansi syariah bisa terealisasikan dengan baik pada perbankan syariah yang masih menganut tujuan utamanya adalah profit oriented. Jadi relevansi pemikiran Iwan Triyuwono tentang akuntansi kelembagaan ekonomi syariah sampai saat ini masih sebuah konsep belum secara keseluruhan bisa diaplikasikan pada kelembagaan syariah. Akan tetapi, jika teori dan konsep yang ditawarkan Iwan Triyuwono bisa diterima dan dipraktikkan dalam kegiatan bisnis sebuah perusahaan ataupun dalam keseluruhan sistem bisnis, tidak menutup kemungkinan terciptanya realitas organisasi dengan jaringan kuasa ilahi. Dan tidak menutup kemungkinan juga aliran pemikiran beliau saling bersinergi untuk membangun konsep akuntansi yang lebih sempurna. Perkembangannya menyesuaikan dengan perkembangan bisnis syariah.

\section{PENUTUP}

Berdasarkan hasil pembahasan pada bab sebelumnya maka dapat ditarik kesimpulan bahwa pemikiran Iwan Triyuwono tentang akuntansi kelembagaan ekonomi syariah, yaitu sebagai berikut.

1. Existing implementasi akuntansi di lembaga keuangan sudah tidak dapat dipungkiri lagi. Keberadaan akuntansi memiliki peran sangat penting terkait lembaga keuangan dalam kegiatannya membutuhkan akuntansi sebagai alat yang menyediakan informasi secara akurat dan dapat bermanfaat untuk keberlangsungan suatu perusahaan.

Adapun pemikiran Iwan Triyuwono yang pertama tentang Shari'ah enterprise theory merupakankerangka akuntansi dalam bingkai syariah yang memiliki perbedaan mendasar pada prinsip akuntansi modern saat ini yang bersifat maskulin, karena pada prinsipnya akuntansi modern saat ini lebih mengutamakan pemilik individu atau kelompok yang sangat

\footnotetext{
${ }^{17}$ Sofyan S. Harahap, Akuntansi Islam.., h.82.
} 
penting dan sentral (proprietary theory dan entity theory), sedangkan Shari'ah enterprise theory menurut Iwan Triyuwono lebih bersifat holistik dan dengan pengakuan adanya pihak lain selain pemilik perusahaan sebagai pihak yang memiliki peran penting bagi kesinambungan hidup perusahaan. Shari'ah enterprise theory (SET) Tuhan sebagai pusat

Telah diketahui bahwa enterprise theory lebih sarat dengan nilai-nilai kapitalisme. Namun demikian, enterpise theory perlu dikembangkan lagi agar memiliki bentuk yang lebih dekat lagi dengan syariah.Pengembangan dilakukan berdasarkan pada metafora zakat pada dasarnya memiliki karakter keseimbangan, hingga akhirnya diperoleh bentuk teori dikenal dengan istilah Shari'ah enterprise theory.

Pemikiran Iwan Triyuwono tentang Sinergi oposisi biner pola pikir Iwan Triyuwono tentang teori ini yaitu akuntansi syariah memiliki konsep berpasangan menghendaki bentuk yang berbeda, yaitu dengan cara mensinergikan dua hal yang berbeda untuk menghasilkan kekuatan yang lebih besar. Dengan konsep ini, akuntansi syariah memasukkan konsep nilainilai maskulin dengan nilai-nilai fenimin, yakni antara kepentingan pemilik individu atau kelompok dipadukan dengan pihak lain sebagai pameran penting keberhasilan sebuah perusahaan.

2. Relevansi pemikiran Iwan Triyuwono tentang akuntansi kelembagaan ekonomi syariah belum mampu sepenuhnya diterapkan pada kelembagaan ekonomi syariah. Mengingat kembali akuntansi syariah tidak dapat dipahami melalui pendekatan konvensional karena ia merupakan instrumen bisnis yang terkait dengan Tuhan, manusia, dan alam. Keterkaitannya dengan Tuhan, manusia, dan alam ini telah membedakan akuntansi syariah dengan akuntansi modern secara signifikan, baik pada nilai yang terkandung di dalamnya maupun pada bentuk teori dan tujuan dasarnya (the basic objective). Dalam konteks bahasan ini, manusia diasumsikan sebagai khalifatullah fil ardhyang membawa amanah Tuhan untuk menciptakan dan menyebarkan rahmat bagi seluruh alam. Dengan pokok pemikiran Iwan Triyuwono tentang akuntansi kelembagaan ekonomi syariah ini merupakan sebuah konsep yang sangat tepat. Hanya saja dengan konsep pemikiran beliau belum bisa terealisasikan, khususnya pada kelembagaan yang berbasis syariah. Hal ini dikarenakan akuntansi praktis lebih banyak diminati. Jadi, perkembangan bisnis saat ini masih menyesuaikan kebutuhan industri yang menginginkan secara praktis (profit oriented).

\section{DAFTAR PUSTAKA}

Adiwarman. 2001. Ekonomi Islam Suatu Kajian Kontemporer. Jakarta: Gema Insani Press.

Bakri, Asafri Jaya. 1996. Konsep Maqashid Syariah Menurut Asy-Syatibi. Jakarta: Raja Grafindo Persada.

Depag RI. (tt). Al-'Aliyy Al-Quran dan Terjemahannya. Bandung: Diponegoro.

Hasan, Nurul Ichsan. 2014. Perbankan Syariah (Sebuah Pengantar). Jakarta: GP Press Group.

http:/ / referensiakuntansi.blogspot.co.id/ 2012/ 07/ pengertian-akuntansi-syariah.html\#sthash.KLj88jFn.dpuf, diakses 17 maret 2016.

IKIT. 2015. Akuntansi Penghimpun Dana Bank Syariah. Yogyakarta: Deepublish. 
Muhammad. 2013. Akuntansi Syariah Teori dan Praktik Untuk Perbankan Syaria. Yogyakarta: UPP STIM YKPN.

Sugiyarta. 2009. Teori Akuntansi dan Laporan Keuangan Islami. Semarang: Badan Penerbit Universitas Diponegoro.

Triyuwono, Iwan. 2003. Sinergi Oposisi Biner: Formulasi Tujuan Dasar Laporan Keuangan Akuntansi Syariah. Universitas Brawijaya: IQTISAD Journal of Islamic Economics, Vol. 4, No. 1, Muharram 1424 H/ March 2003.

Warsono, Sony. 2011. Akuntansi Transaksi Syariah. Yogyakarta: Asgard Chapter. 